\title{
PENGARUH TATAGUNA LAHAN TERHADAP BESARAN BANJIR DAN SEDIMEN DAS KRUENG KEUREUTO ACEH UTARA
}

\author{
Muhammad Kabir Ihsan \\ Jurusan Teknik Sipil, Fakultas Teknik, Universitas Malikussaleh
}

\begin{abstract}
Abstrak
Penelitian banjir dan sedimen Sungai Krueng (Kr) Keureuto dilakukan untuk mengetahui pengaruh perubahan data guna lahan dan perilaku sedimen. Lingkup penulisan meliputi pengumpulan data sedimen, peta daerah aliran sungai (DAS), data curah hujan, penentuan curah hujan dan debit banjir rencana, analisa sedimen DAS dan perhitungan produksi sedimen akibat banjir. Metode yang digunakan dalam analisa hidrologi adalah metode momen. Hasil analisa menunjukkan bahwa data hujan cenderung mengikuti distribusi harga ekstrim (extreme value), sedangkan hubungan cerah hujan dan debit banjir rencana menunjukkan hubungan logaritmik. Hubungan linear diperoleh untuk korelasi antara besarnya debit banjir dan debit sedimen. Hasil penelitian ini sangat bermanfaat untuk program penanggulangan banjir Sungai Krueng Keureuto.
\end{abstract}

Kata kunci: banjir, sedimen, momen statistik

\section{Pendahuluan}

Dalam pengembangan sumber daya air (water resources development), pembahasan banjir dan sedimen sangat penting karena terkait kehidupan orang banyak dan lingkungan. Banjir merupakan kejadian akan tetapi menjadi sebuah permasalahan setelah terjadi konflik kepentingan dengan kehidupan masyarakat. Pada saat banjir, sungai mengangkut sedimen yang dapat merubah morfologi sungai dengan terjadinya endapan yang mengurangi kapasitas aliran. Sungai merupakan sumber air dan material bangunan. Penambangan galian $\mathrm{C}$ yang melebihi kapasitas produksi sedimen akan menimbulkan permasalahan lainnya.

Kejadian banjir dan masalah sedimen juga terjadi di Sungai Krueng Keureuto, salah satu sungai di Kabupaten Aceh Utara yang berada di satuan wilayah sungai (SWS) 01.01.03 Pase Peusangan. Banjir tersebut telah merusak permukiman, tanaman pangan, perumahan, gedung fasilitas umum, dan infrastruktur prasarana dasar lainnya. Kota Lhoksukon sebagai ibukota Kabupaten Aceh Utara terletak pada kawasan rawan banjir, sehingga setiap datang musim hujan kota tersebut selalu dilanda banjir.

Pemerintah Provinsi Aceh dan Kabupaten Aceh Utara sudah berbuat untuk menanggulangi banjir Sungai $\mathrm{Kr}$ Keureuto, akan tetapi belum berhasil dengan baik. Penanggulangan yang dilakukan sifatnya responsif yang kurang didukung oleh hasil penelitian. Penanggulangan banjir harus kenal pasti proses dan karakteristik banjir. Apabila hal ini dilupakan maka bukannya permasalahannya yang dapat ditanggulangi akan tetapi menimbulkan masalah baru yang lebih komplek penanggulangannya dan memerlukan teknologi dan dana yang lebih besar. 
Banjir terjadi karena curah hujan dengan intensitas tinggi dan rusaknya daerah tangkapan hujan di bagian hulu. Banjir yang membawa sedimen akan mempengaruhi badan sungai, yaitu pengendapan sedimen dan erosi tebing sungai. Dua topik masalah banjir dan sedimen ini dipilih menjadi topik bahasan dalam studi ini, dengan mengambil Sungai Kr Keureuto sebagai sampel. Alasan pengambilan Sungai Kr Keureuto sebagai sungai bahasan karena sungai ini mengalir melalui kota Lhoksukon di bagian hilir DAS, sedangkan dibagian hulu DAS terjadi pengembangan yang relatif cukup pesat seperti adanya kawasan transmigrasi di Cot Girek. Adanya perubahan tata guna lahan di DAS dan perilaku masyarakat dalam memanfaatkan sungai serta adanya pembangunan kota Lhoksukon, maka akan terjadi perubahan hidrologis sungai. Perubahan dimaksud seperti meningkatnya volume dan frekuensi banjir serta genangan. Untuk itu perlu dilakukan studi ini sebagai deteksi dini terhadap perilaku Sungai $\mathrm{Kr}$ Keureuto yang terkait dengan proses terjadinya banjir dan angkutan sedimen.

\section{Telaah Kepustakaan}

Karakteristik DAS memberikan informasi tentang luas DAS, panjang sungai dan kemiringan sungai (Pucell, 2007). Panjang sungai merupakan jalur aliran sungai dari hulu hingga ke laut, danau atau tempat observasi. Kemiringan sungai merupakan perbandingan antara beda elevasi hulu dan hilir dibagi dengan panjang sungai.

\subsection{Curah Hujan Rencana}

Penentuan besarnya curah hujan memerlukan tahapan pengumpulan data dan analisa frekuensi. Data curah hujan mempunyai satuan tinggi $\mathrm{mm}$ atau inchi yang dikumpulkan dari stasiun pencatat curah hujan, baik pencatat manual atau otomatis. Dalam analisa ekstrim digunakan data ekstrim dengan mengambil satu data maksimum dalam siklus satu tahun (апnual series), yaitu data harian maksimum tahunan (Haan, 1997).

Distribusi yang sering digunakan dalam analisa curah hujan adalah distribusi Normal (N), Lognormal (LN), Log Pearson (LP), Gamma (GAM), harga ekstrim ( $\mathrm{EV}$ ) dan lainya. Distribusi data dapat ditentukan berdasarkan parameter statistik, seperti koefisien variasi $\left(\mathrm{C}_{\mathrm{v}}\right)$, koefisien kemencengan $\left(\mathrm{C}_{\mathrm{s}}\right)$ dan koefisien kurtosis $\left(\mathrm{C}_{\mathrm{k}}\right)$. Penentuan distribusi yang paling simpel adalah dengan membandingkan nilai $\mathrm{C}_{\mathrm{v}}$ dan $\mathrm{C}_{\mathrm{s}}$ ( Triatmodjo, 2008 ). Data mengikuti distribusi Normal apabila $\mathrm{C}_{\mathrm{s}} \approx 0$ dan mengikuti distribusi Log Normal apabila $\mathrm{C}_{\mathrm{s}} \approx\left(3 \mathrm{C}_{\mathrm{v}}+\right.$ $\mathrm{C}_{\mathrm{v}}^{3}$ ). Data mengikuti distribusi harga ekstrim kalau tidak terdistribusi secara Normal dan Log Normal. Besarnya nilai parameter statistik dapat dicari berdasarkan nilai momen parameter statistik (Rao dan Hamed, 2000).

Analisa frekuensi adalah memprediksi parameter dan besarnya curah hujan untuk periode ulang tertentu. Rao dan Hamed (2000) memberikan bentuk lain yang menggunakan momen parameter statistik dan besarnya nilai $\mathrm{R}_{\mathrm{T}}$ yang ditentukan dengan menggunakan Rumus (1) hingga (3).

$$
\begin{gathered}
R_{T}=\beta-\alpha \operatorname{Ln}\{-\operatorname{Ln}(1-1 / T)\} \\
\alpha=\frac{\sqrt{6}}{\pi} \sqrt{m^{2}}
\end{gathered}
$$




$$
\beta=m_{1}-0.45005 \sqrt{m_{2}}
$$

\subsection{Debit Banjir Rencana}

Menurut Loebis (1986), rumus umum perhitungan debit banjir rencana merupakan fungsi dari koefisien limpasan, koefisien reduksi, besarnya intensitas curah hujan dan luas DAS. Apabila ingin diketahui lamanya waktu tercapainya debit puncak maka perhitungan debit dapat digunakan dengan metode Hidrograf satuan Sintesis (HSS). Salah satu HSS adalah yang diperkenalkan oleh Snyder ( Sri Harto, 2000: Triatmodjo, 2008). Besarnya debit yang dihasilkan oleh metode HSS adalah besarnya debit untuk curah hujan sebesar $1 \mathrm{~mm}$ selama waktu hujan $\mathrm{t}_{\mathrm{r}}$ (jam) dan luas DAS sebesar $A \mathrm{~km}^{2}$. Jadi untuk debit yang dihasilkan oleh curah hujan rencana perlu dilihat hyetografinya. Hyetograf hujan perskala waktu dapat berbentuk konstan, segitiga, alternating blok ataupun blok puncak.

\subsection{Produksi Sedimen DAS}

Sedimen lahan terjadi karena proses pelapukan tanah yang terlepas terkena energi air hujan dan bergerak karena adanya limpasan. Menurut Vanoni (1977) sedimen DAS dapat berbentuk sedimen permukaan, sedimen alur-alur kecil ataupun alur runtuhan. Banyaknya produksi sedimen untuk setiap kejadian hujan diperkenalkan oleh William dan Berdt pada tahun 1972 (Simons dan Senturk, 1992). Rumus produksi sedimen lahan untuk satu kejadian hujan adalah rumus Modified Universal Soil Loss Equation (MUSLE) seperti (4).

$$
\mathrm{Y}_{\mathrm{s}}=\alpha\left(\mathrm{Q}_{\mathrm{v}} \mathrm{q}_{\mathrm{p}}\right)^{\beta} K L S C P
$$

Dengan $\mathrm{Y}_{\mathrm{s}}=$ produksi sedimen untukper-kejadian hujan (ton), $\mathrm{Q}_{\mathrm{v}}=$ volume limpasan (acre $f t), \mathrm{q}_{\mathrm{p}}=$ debit puncak $\left(\mathrm{ft}^{3} / \mathrm{det}\right), \alpha$ dan $\beta$ adalah koefisien yang nilainya masing-masing adalh 95 dan 0.56 . variable $K=$ erodibilitas tanah, $L$ dan $S$ $=$ faktor topografis lahan, $C$ dan $P=$ jenis tanaman dan manajemen praktis yang diterapkan di lahan. Untuk menghitung produksi sedimen, produksi sedimen setiap kejadian hujan perlu dikalikan dengan nilai perbandingan volume air tahunan dengan probabilitas produksi air. Periode ulang yang disarankan adalah 2-, 10-, 25- dan 100- tahun. Rumus produksi sedimen tahunan adalah Rumus (5).

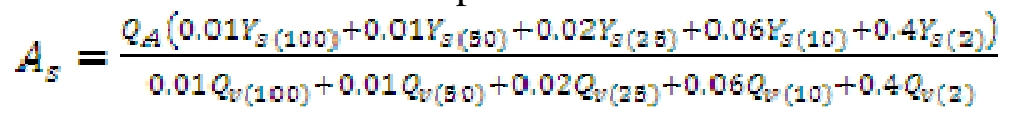

dimana: $\mathrm{A}_{\mathrm{s}}=$ produksi desimen tahunan, $\mathrm{Q}_{\mathrm{A}}=$ produksi air rata-rata tahunan, dan $\mathrm{Q}_{\mathrm{v}}=$ produksi volume air untuk setiap periode ulang kejadian hujan. Karena aliran banjir fluktuatif, maka pada saat debit rendah sebagian angkutan sedimen terutama butiran yang lebih besatr akan mengendap di sepanjang sungai.

\subsection{Hidraulika Sungai}

Angkutan sedimen sungai proporsional terhadap besarnya debit. Konsep aliran seragam sebenarnya jarang terjadi di sungai karena bentuk sungai yang tidak beraturan. Dengan menganggap sungai yang panjang dan lebar, maka konsep tersebut dapat digunakan sebagai pendekatan. Menurut Olsen (2007:7), besarnya gaya seret merupakan fungsi dari kerapatan massa air, tinggi aliran dan 
kemiringan garis energy. Distribusi kecepatan aliran menunjukkan bahwa nilai terendah terjadi pada dasar sungai dan tercepat pada bawah muka air.

Debit merupakan fungsi dari luas tampang aliran dan kecepatan rata-rata dimana kecepatan aliran dipengaruhi oleh karakteristi tampang dan kekasaran dinding sungai. Rumus kecepatan aliran yang cukup terkenal adalah Rumus Manning seperti (Olsen, 2007: 8). Nilai kekasaran Manning mempunyai korelasi dengan kekasaran yang diberikan oleh Strickler, dengan hubungan $M=1 / n$ dengan (6),

$$
\mathrm{M}=26 /\left(\mathrm{d}_{90}\right)^{1 / 6}
$$

Dengan diketahui besarnya kecepatan aliran dan koefisien kekasaran maka kedalaman aliran dapat ditentukan. Besarnya debit aliran persatuan lebar sungai menjadi : $q=V h$.

\subsection{Kemiringan Garis Energi}

Aliran terjadi karena ada beda potensial dan kecepatan aliran yang dipengaruhi oleh kemiringan garis energi sebagai fungsi dari kemiringan dasar sungai. Besarnya kemiringan energi merupakan bagian dari tinggi tekan total yang merupakan fungsi elevasi dasar terhadap datum, kedalaman aliran dan kehilangan energi. Dengan menggunakan rumus kekasaran Manning, maka besarnya kemiringan garis energy dituliskan seperti Rumus (7).

$$
I_{f}=\frac{V^{2}}{M^{2} h^{4 / 2}}=\frac{Q^{2}}{M^{2} B^{2} h^{10 / 2}}
$$

\subsection{Debit Sedimen Sungai}

Proses angkutan atau pergerakan sedimen dapat berbentuk sedimen melayang (suspended sediment), transisi (wash load) dan sedimen dasar (bed load). Ketiga jenis ini berjalan bersamaan di aliran banjir sesuai dengan diameter butiran sebagai sedimen total. Produksi sedimen total yang ditemukan oleh Engelund dan Hansen pada 1967 adalah seperti berikut (Olsen, 2007: 105).

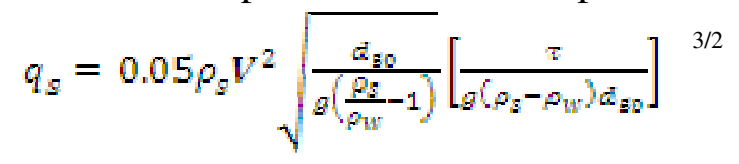

$q_{s}=$ sedimen dasar (ton); $g=$ percepatan gravitasi $\left(\mathrm{m} / \mathrm{det}^{2}\right) ; \rho_{s}=$ rapat massa sedimen; $\rho_{w}=$ rapat massa air; $R_{h}=$ radius hidraulis $(\mathrm{m}) ; \mathrm{d}_{50}=$ median diameter.

\section{Metodologi}

Pemilihan Sungai Kr Keureuto sebagai sampel studi karena sungai ini sering terjadi banjir khususnya kawasan sekitar kota. Hal ini dilakukan karena data yang terkait dengan Sungai Kr Keureuto relatif cukup tersedia. Peta DAS Kr Keureuto dapat disajikan pada Gambar 1.

\subsection{Pengumpulan Data}

Peta DAS diambil dari Aceh Design Unit (1986). Karena tidak diperoleh data debit, maka besarnya debit sungai diperkirakan dengan memakai data hujan yang diambil dari BPP Kota Lhoksukon. Data hidrometri diambil dengan cara 
pengukuran debit dan pengambilan sampel sedimen. Pengukuran hidrometri dilakukan pada dua tampang yang membentuk satu pias sungai.

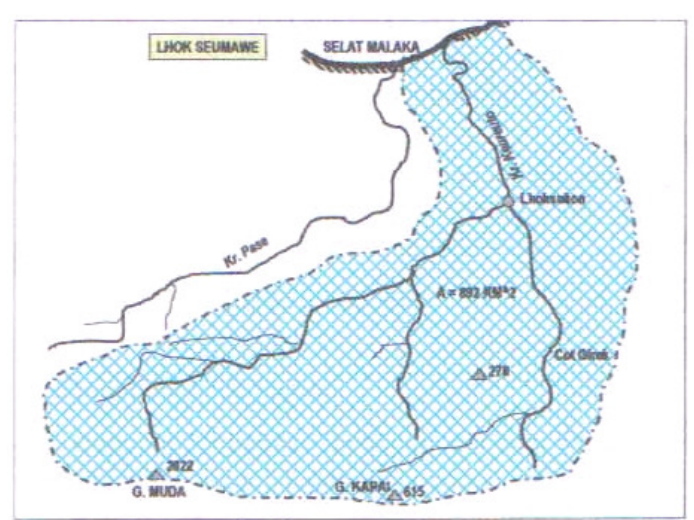

\section{Gambar 1 Daerah aliran sungai Kr Keureuto Sumber: Aceh Design Unit (1986)}

Kecepatan diukur pada titik $0.2 d, 0.6 d$ dan $0.8 d$ dimana $d$ adalah kedalaman aliran. Digunakan alat "currentmeter" digital merk TATONAS. Lokasi pengukuran di Desa Meunasah Mee (I) dan Desa Teupin Gapeuh (II) berjarak sekitar $500 \mathrm{~m}$ dari kota Lhoksukon, sedangkan tampang II berjarak $1500 \mathrm{~m}$.

\subsection{Analisa Data Curah Hujan}

Luas DAS Kr Keureuto hingga ke muara adalah $892 \mathrm{~km}^{2}$, sedangkan luas hingga lokasi tinjauan adalah seluas $745 \mathrm{~km}^{2}$. Panjang sungai hingga lokasi observasi $71.50 \mathrm{~km}$ dan kemiringan 0.00254. distribusi curah hujan ditentukan berdasarkan parameter statistik dengan menggunakan metode momen statistik. Apabila data tidak mengikuti sebaran Normal dan Log Normal maka dianggap mengikuti sebaran harga ekstrim dan akan digunakan harga ekstrim tipe I. sebaran ini dikenal dengan nama distribusi Gumbel. Analisa frekuensi dimaksudkan untuk menentukan kuantil curah hujan untuk periode ulang 2-, 5-, 10-, 20-, 50-, 100tahun dan curah hujan PMP. Metode perhitungannya dipilih metode momen statistik untuk penyebaran harga ekstrim tipe I. untuk menentukan besarnya curah hujan PMP maka digunakan nilai faktor frekuensi $K=15$ (Chin, 2006).

\subsection{Perhitungan Debit Banjir Bencana}

Debit banjir bencana yang setidaknya dapat menunjukkan besarnya debit puncak, waktu puncak dan waktu dasar hidrograf. Pada rumus HSS Snyder diambil durasi hujan sebesar 4 jam, sehingga masukan durasi hujan sama dengan durasi hujan pada HSS Snyder. Dengan demikian debit banjir merupaka superimpose 6 buah hidrograf banjir.

\subsection{Hubungan Banjir dan Tata Guna Lahan}

Dalam rumus HSS Snyder terdapat konstanta $C_{t}$ yang didalamnya terdapat fungsi tata guna lahan, sedangkan konstanta $C_{p}$ terkait manajemen praktis pengelolaan DAS. Nilai $\mathrm{C}_{t}$ ini berkisar antara 1.4 dan 1.7, sedang nilai $\mathrm{C}_{p}$ berkisar antara 0.15 dan 0.19. nilai $\mathrm{C}_{p}$ dan $\mathrm{C}_{t}$ adalah berpasangan terbalik dimana nilai $\mathrm{C}_{t}$ besar maka nila $\mathrm{C}_{p}$ cenderung menjadi kecil. Dengan demikian maka sebagai masukan dalam perhitungan HSS Snyder dibuat skenario untuk mendapatkan 
hidrograf banjir bagi kombinasi $\mathrm{C}_{p}$ dan $\mathrm{C}_{t}$. Perubahan nilai $\mathrm{C}_{t}$ sebagai fungsi tata guna lahan akan merubah besarnya puncak banjir, waktu puncak banjir dan waktu dasar hidrograf.

\subsection{Analisa Sendimen DAS}

Rumus perkiraan produksi tahunan sendimen DAS adalah rumus (4) dan (5) digunakan untuk menghitung produksi sendimen untuk setiap kejadian hujan. Pada rumus (12) dikehendaki adanya data debit banjir untuk periode ulang 2-, 10-, 25-, 50- dan 100- tahun. Akan tetapi dalam perhitungan sedimen DAS sebesar debit banjir rencana dalam satuan $\mathrm{m}^{3} /$ det perlu ditransfer menjadi volume air $\left(\mathrm{m}^{3}\right)$. Konstanta pada masing-masing debit banjir terhadap produksi sendimen.

\subsection{Analisa Debit Sendimen}

Dengan diketahui nilai kecepatan aliran maka perlu dicari besarnya nilai kekasaran sungai yang ditentukan berdasarkan ukuran diameter butiran seperti pada rumus (8). Variabel lain adalah kemiringan garis energi $\left(I_{f}\right)$ yang juga merupakan fungsi ukuran diameter butiran disamping fungsi parameter aliran lainnya. Besar debit sedimen proposional terhadap debit banjir. Rumus (8) digunakan untuk menghitung produksi angkutan sendimen.

\section{Hasil dan Pembahasan}

Luas DAS pada lokasi tinjauan adalah $745 \mathrm{~km} 2$ dengan panjang sungai 71.5 dan kemiringan sungai 0.0254 .

\subsection{Curah Hujan Rencana}

Perhitungan curah hujan rencana digunakan metode biasa dan didapat besarnya koefisien parameter statistik : $\mathrm{C}_{v}=0.29, \mathrm{C}_{s}=-0.73$ dan $\mathrm{C}_{k}=3.11$. Curah hujan tidak mengikuti sebaran normal maupun Log Normal, sehingga dianggap mengikuti penyebaran harga ekstrim. Sebaran harga ekstrim yang digunakan harga esktrim tipe I. Pada analisa frekuensi dihitung besarnya hujan rencana untuk periode ulang 2-, 5-, 10-, 20-, 50-, 100-tahun dan PMP. Untuk itu perlu dicari besarnya nilai rata-rata $\beta$ dan standar deviasi $\alpha$ serta nilai faktor frekuensi $K$. Nilai $K$ untuk menentukan curah hujan PMP diambil sebesar 15. Hasil perhitungan curah hujan rencana di plot dalam sebuah grafik dan diperoleh hubungan.

$$
R_{T}=17.45 \operatorname{Ln}(T)+65.344
$$

\subsection{Debit Banjir Rencana}

Dalam hasil Snyder dipakai $t_{r}=4$ jam. Menurur Chin (2006) nilai $\mathrm{C}_{t}$ dan $\mathrm{C}_{p}$ saling berpasangan dalam artian kalau nilai $\mathrm{C}_{t}$ besar maka nilai $\mathrm{C}_{p}$ kecil dan sebaliknya. Konstanta $\mathrm{C}_{t}$ terkait dengan tata guna lahan dan nilainya mengecil apabila tata guna lahan cenderung menurun dengan meningkatnya koefisien limpasan. Untuk itu ditetapkan pasangan $\mathrm{C}_{t}$ dan $\mathrm{C}_{p}$ seperti $(0.4 ; 1.65),(0.5 ; 1.58)$, $(0.6 ; 1.50),(0.7 ; 1.43)$ dan $(0.8 ; 1.35)$. Hasil perhitungan di plot hidrografinya dapat dilihat pada Gambar 2. Dari gambar 2 terlihat bahwa perubahan nilai $\mathrm{C}_{t}$ dari besar ke kecil mempunyai dampak langsung terhadap perubahan debit maksimum $\left(\mathrm{Q}_{\text {mak }}\right)$, waktu puncak $\left(t_{p}\right)$ dan waktu dasar hidrograf $\left(\mathrm{T}_{b}\right)$. 


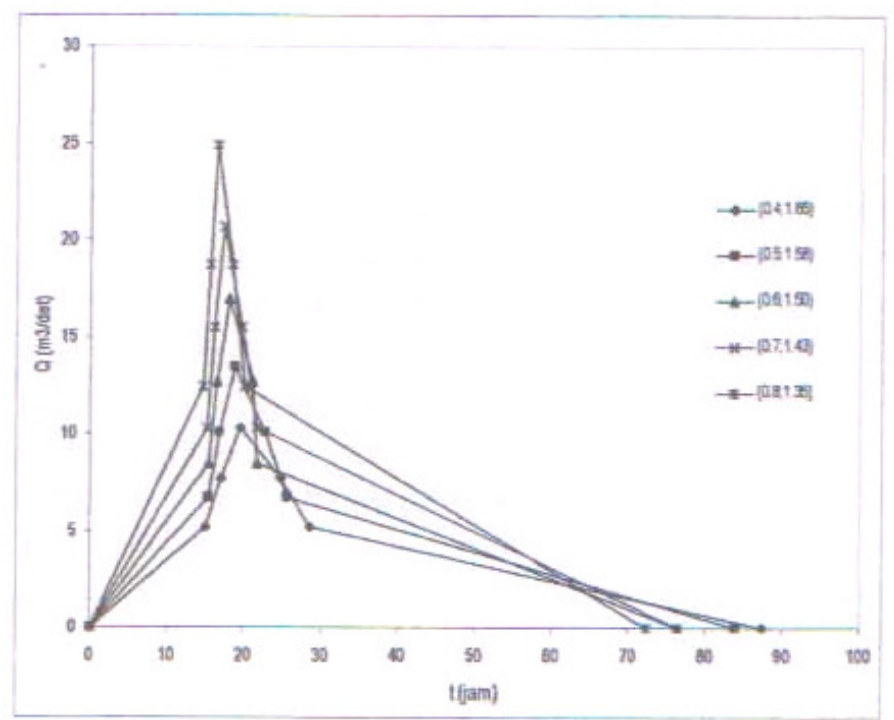

Gambar 2 Unit Hidrograf HHS Snyder

Debit banjir rencana diperhitungkan berdasarkan nilai tengahC $\mathrm{C}_{t}=1.5$ dan nilai $\mathrm{C}_{p}=0.6$. Langkah didapatkan debit dengan mengalihkan besarnya debit dari hasil perhitungan HSS Snyder dengan besaran curah hujan rencana untuk setiap segmen. Hasil perhitungan untuk $T=2$-tahun disajikan pada plotting Gambar 3. Dari Gambar 4 menunjukkan pola hidrograf untuk semua periode ulang dari 2hingga 100-tahun mempunyai bentuk dan waktu dasar yang sama. Waktu dasar (time base) diperoleh sebesar 100 jam, sedangkan puncak debit bervariasi sesuai dengan periode ulang banjir masing-masing. Hidrograf pada gambar 4 juga memperlihatkan adanya enam buah puncak banjir puncak banjir tertinggi tercapai pada jam ke-34 untuk semua periode ulang banjir.

Untuk menggeneralisir hasil perhitungan maka hasil debit banjir rencana di plot dalam sebuah grafik dan ditentukan rumus prediksinya. Grafik hubungan antara periode ulang dan desarnya debit banjir bertendensi untuk mengikuti kurva logaritmik (Gambar 5 )

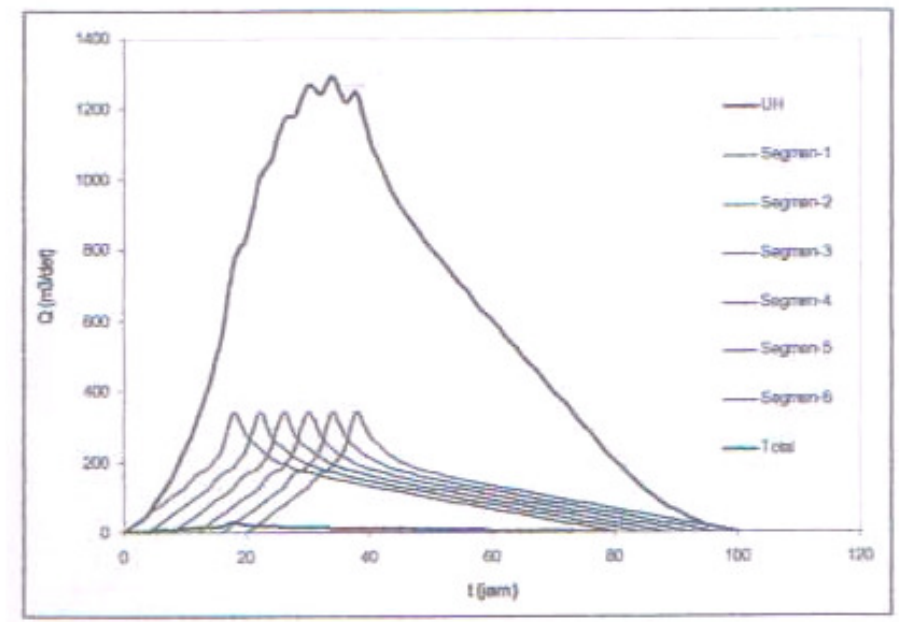

Gambar 3 Hidrograf debit banjir T = 2-tahun 


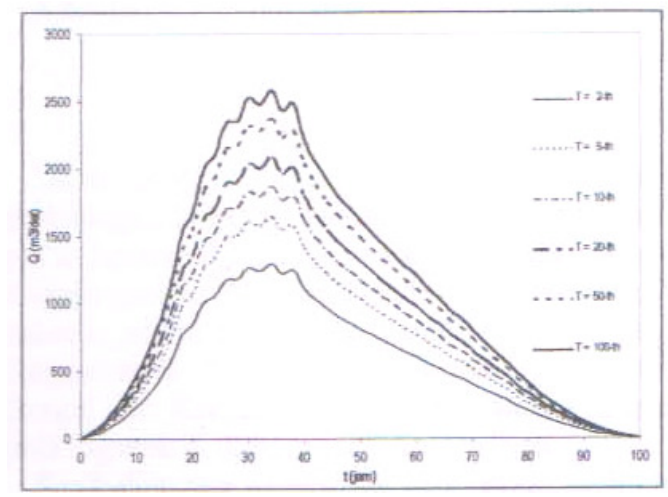

Gambar 4 Hidrograf debit banjir

\subsection{Analisa Sendimen Lahan}

Setiap kejadian hujan akan memproduksi sedimen lahan dan kejadian hujan diperhitungkan menurut periode ulangnya. Produksi sedimen yang dihasilkan $\left(Y_{s}\right)$ dalam satuan (ton) dihitung dengan menggunakan rumus (5). Penentuan nilai $Q_{A}$ mempergunakan besaran curah hujan tahunan pada kawasan tersebut, yaitu berkisar 1000 - $4000 \mathrm{~mm}$. Hasil perhitungan di plot dan terlihat bahwa hubungan antara curah hujan dan produksi sendimen DAS mengikuti garis lurus :

$$
\mathrm{A}_{\mathrm{s}}=6.3657 * \overline{R_{a}}
$$

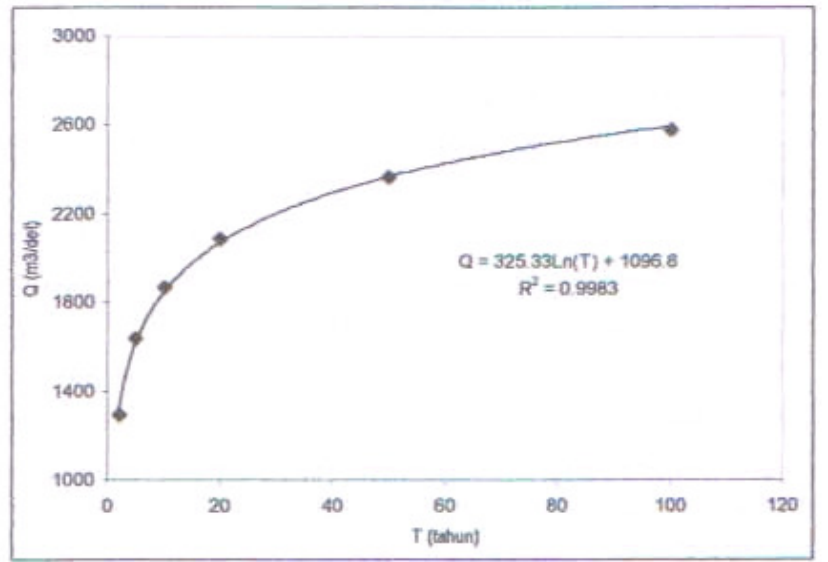

Gambar 5 Debit banjir rencana

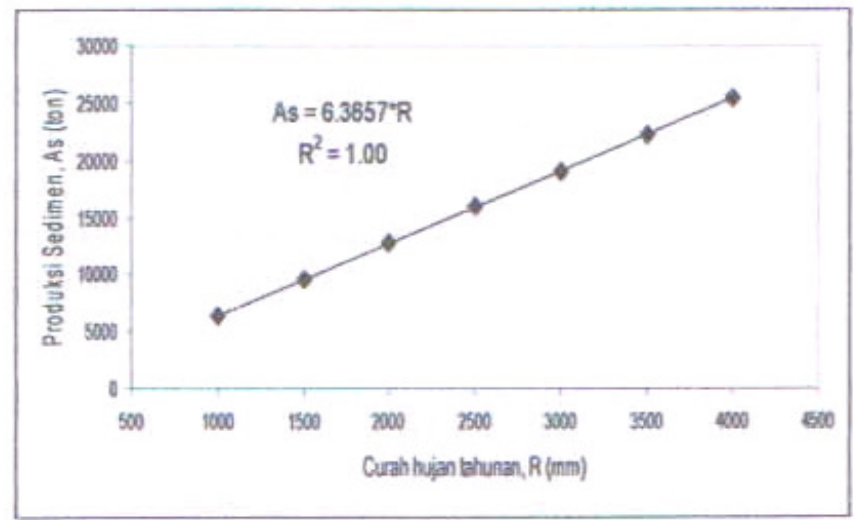

Gambar 6 Produksi sedimen lahan 


\subsection{Analisa Sendimen Sungai}

Hasil pengukuran debit diperoleh sebesar $111.07 \mathrm{~m}^{3} / \mathrm{det}$ (I) dan 111.60 $\mathrm{m}^{3} /$ det (I). Luas tampang dan kecepatan aliran $0.58 \mathrm{~m} / \mathrm{det}$ (I), sedang di (II) luas $252.50 \mathrm{~m}^{2}$ dan kecepatan aliran $0.44 \mathrm{~m} /$ det. Hasil uji sampel sedimen memperlihatkan nilai rata - rata $S G=2.45$ dan median diameter $0.010 \mathrm{~mm}$.

Profil vertikal distribusi kecepatan aliran memperlihatkan bahwa kecepatan aliran pada Tampang I lebih kecil dibandingkan dengan kecepatan pada Tampang II. Kecepatan aliran hasil pengukuran di lapangan, yaitu $0.50 \mathrm{~m} / \mathrm{det}$ dan 0.44 $\mathrm{m} /$ det terjadi kebalikan nilai dimana kecepatan pada tampang I lebih besar dari kecepatan Tampang II. Hal ini dapat saja terjadi karena nilai yang dihasilkan adalah kecepatan rata-rata perhitungan debit dibagi dengan besarnya luas aliran total.

\subsection{Produksi Sendimen Sungai}

Dalam studi ini tampang sungai $\mathrm{Kr}$ Keureuto disimplikasikan menjadi bentuk tampang tersusun, dimana pada kedalaman $\mathrm{h}<10 \mathrm{~m}$, tampang saluran berbentuk tumpang tunggal (single channel) sedangkan untuk $\mathrm{h}>10 \mathrm{~m}$ menjadi tampang tersusun (compound channel), dengan kemiringan memanjang sungai 1:10.000. Debit sendimen dihitung hingga kapasitas aliran di sungai terjadi aliran maksimum (full bank discharge) karena pada debit yang lebih besar aliran sudah melimpah dari tanggul. Perhitungan debit total digunakan Rumus (5) dengan menggantikan parameter $\gamma=\rho^{*} g$ sesuai dengan rumus pada ASCE Manual No. 54 (Vanoni, 1975). Setiap besaran debit Q ( $\mathrm{m}^{3} / \mathrm{det}$ ) menghasilkan debit sedimen $q_{s}$ (kg/det.m) yang hasilnya di plot dalam sebuah grafik seperti pada Gambar 7 yang memperlihatkan korelasi antara debit air dan debit sedimen dalam persamaan : qs $=0.00076^{*} \mathrm{Q} 0 .{ }^{8275}$. Besarnya produksi sedimen masih memerlukan data lebar sungai dan hidrograf banjir. Untuk debit banjir rencana periode ulang 2-tahun sebesar $1293.43 \mathrm{~m}^{3} / \mathrm{det}$, Kr Keureuto dengan lebar sungai $50.0 \mathrm{~m}$ dan waktu dasar hidrograf 100 jam akan memproduksikan sedimen 242.17 ton.

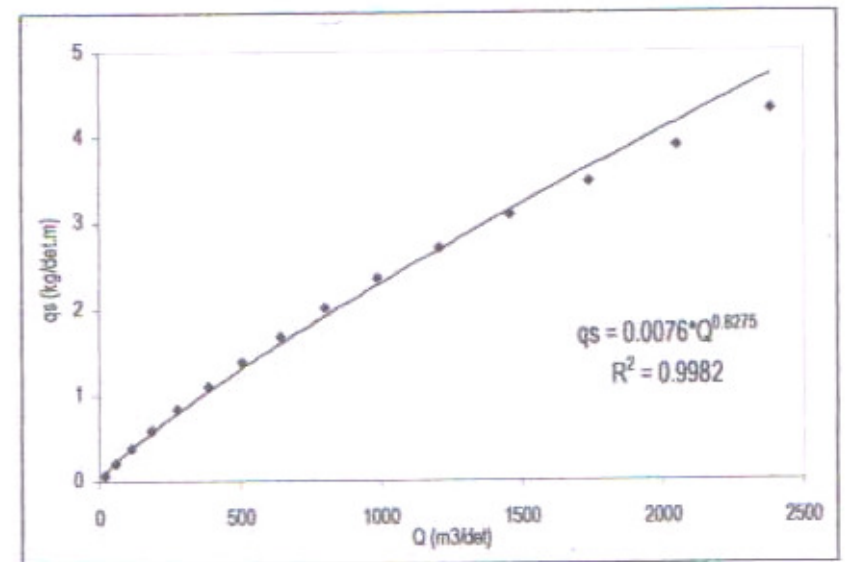

Gambar 7. Hubungan debit dan debit sedimen

\section{Kesimpulan}

Berdasarkan hasil analisa, perhitungan dan diskusi yang dilakukan dalam studi ini maka dapat diambil beberapa kesimpulan yang antara lain adalah sebagai berikut : 
1. Data curah hujan yang digunakan tidak mengikuti sebaran Normal maupun Log Normal, sehingga dalam analisa digunakan distribusi harga ekstrim (extreme values).

2. Penggunaan metode momen statistik menunjukkan bahwa hubungan antara besaran curah hujan dan periode ulang mengikuti hubungan logaritmik, demikian juga untuk debit maksimum.

3. Besarnya puncak banjir terjadi pada jam ke-34 sedangkan waktu dasar banjir adalah 100 jam.

4. Dampak perubahan tata guna lahan terhadap banjir adalah meningkatnya debit puncak, memperpendek waktu puncak banjir dan memperpendek waktu dasar banjir.

5. Produksi tahunan sedimen lahan ditentukan berdasarkan curah hujan rata-rata tahunan.

6. Sedimen dasar sungai $\mathrm{Kr}$ Keureuto pada pias sungai sekitar Lhoksukon terbentuk dari sedimen seragam (poo graded) dengan diameter median 0.01 $\mathrm{mm}$.

\section{Daftar Kepustakaan}

1. Haan, C.T., 1977, Statistical Method in Hydrology. $4^{\text {th }}$ ed. lowa State University Press, Ames, lowa

2. Loebis, Y, 1980, Perhitungan Debit Banjir Rencana, Departemen Pekerjaan Umum, Jakarta.

3. Olsen, N.R.B, 2007, Numerical Modeling and Hydraulics, Departemen of hydraulic and Enviromental Engineering, the Norwegian University of Science and Technology, Oslo.

4. Pucell, P.J, 2003, Design of Water Resources Systems, Thomas Telford, Tokyo.

5. Rao, A.R., dan K.H. Hamed, 2000, Flood Frequency Analysis, CRC Press, New York.

6. Sri Harto, B, 2000, Hidrologi: Teori, Masalah, Penyelesaian, Nafri, Yogyakarta.

7. Triatmodjo, B, 2008, Hidrologi Terapan, Beta Offset, Yogyakarta.

8. Vanoni, V.A, 1975, Sedimentation Engineering, ASCE Manuals and Reports on Engineering Practice No.54, New York. 